УДК 582.382.22+575.224.234.2

\title{
The cytotypes variability of the complex Selaginella sanguinolenta s. I.
}

\author{
M. V. Skaptsov ${ }^{1 *}$, A.V. Vaganov ${ }^{1}$, A. A. Kechaykin ${ }^{1}$, M. G. Kutsev ${ }^{1}$, S. V. Smirnov ${ }^{1}$, \\ V. I. Dorofeev' ${ }^{2}$, A. E. Borodina-Grabovskaya ${ }^{2}$, A. P. Seregin ${ }^{3}$, T. A. Sinitsina ${ }^{1}$, \\ N. V. Friesen ${ }^{4}$, X.-C. Zhang ${ }^{5}$, A. I. Shmakov ${ }^{1}$ \\ ${ }^{1}$ Altai State University, South-Siberian Botanical Garden, pr. Lenina, 61, Barnaul, 656049, Russian Federation. \\ *E-mail:mr.skaptsov@mail.ru \\ ${ }^{2}$ Russian Academy of Sciences, Komarov Botanical Institute, Professor Popov Str., 2, St. Petersburg, 197376, Russian \\ Federation.E-mail:vdorofeyev@yandex.ru \\ ${ }_{3}^{3}$ Biology Department, Lomonosov Moscow State University, Moscow, 119234, Russia. E-mail: botanik.seregin@gmail.com \\ ${ }^{4}$ Botanical Garden of the University of Osnabrueck, Albrechtstrasse, 29, 490776, Osnabrück, Germany. \\ E-mail:friesen@biologie.uni-osnabrueck.de
}

${ }^{5}$ State Key Laboratory of Systematic and Evolutionary Botany, Institute of Botany, Chinese Academy of Sciences (CAS), Beijing, 100093, China.E-mail: zhangxc@ibcas.ac.cn

* Corresponding author

Keywords: DNA content, endopolyploidy, flow cytometry, genome size, ploidy level, Selaginella.

Summary. The article presents the results of measuring the DNA content by flow cytometry of S. sanguinolenta and $S$. borealis species in 50 populations from natural habitats of Russia and Mongolia. Two probable cytotypes for S. sanguinolenta, as well as single samples with multiple changes, and two cytotypes for $S$. borealis were identified. Samples with the smallest cytotypes are on average 0.32 and $0.38 \mathrm{pg}$ for $S$. sanguinolenta and $0.36 \mathrm{pg}$ for S. borealis. The studied samples with large cytotypes are distributed mainly in the territories southwest and south of the Baikal Lake and concentrate mostly on the boundaries of the distribution areas of S. sanguinolenta and S. borealis. Samples with large cytotypes contain 1.5 times more DNA $(0.49 \mathrm{pg})$ and 2.2 times more $(0.63 \mathrm{pg})$ for S. sanguinolenta and 1.4 times more $(0.49 \mathrm{pg})$ for $S$. borealis from the smallest cytotypes. In addition, we measured the DNA content for 7 species of the sanguinolenta-group and 26 other species of the genus Selaginella. Data for 27 species are presented for the first time.

\section{Вариабельность цитотипов комплекса Selaginella sanguinolenta s. I.}

\author{
М. В. Скапцов ${ }^{1 *}$, А. В. Ваганов ${ }^{1}$, А. А. Кечайкин ${ }^{1}$, М. Г. Куцев ${ }^{1}$, С. В. Смирнов ${ }^{1}$, \\ В. И. Дорофеев ${ }^{2}$ А. Е. Бородина-Грабовская ${ }^{2}$, А. П. Серёгин ${ }^{3}$, Т. А. Синицина ${ }^{1}$, \\ Н. В. Фризен ${ }^{4}$, Х.-С. Zhang ${ }^{5}$, А. И. Шмаков ${ }^{1}$
}
${ }^{1}$ Южно-Сибирский ботанический сад, Алтайский государственный университет, пр. Ленина, 61, г. Барнаул, 656049, Россия
${ }^{2}$ Ботанический институт им. В. Л. Комарова РАН, ул. Профессора Попова, 2, г. Санкт-Петербург, 197376, Россия
${ }^{3}$ Биологический факультет, Московский государственный университет им. М. В. Ломоносова, ул. Ленинские горы, 1, г. Москва, 119234, Россия

${ }^{4}$ Ботанический сад Университета Оснабрюк, Альбрехтитрассе, 29, г. Оснабрюк, 490776, Германия 


\author{
${ }^{5}$ Государственная ведущая лаборатория систематики и эволюиионной ботаники, Институт ботаники, \\ Китайская Академия наук (КАН), г. Пекин, 100093, Китай \\ *Автор для переписки
}

Ключевые слова: проточная цитометрия, размер генома, содержание ДНК, уровень плоидности, эндополиплоидия, Selaginella.

Аннотация. В работе представлены результаты измерения содержания ДНК методом проточной цитометрии видов $S$. sanguinolenta и $S$. borealis в 50 популяциях из природных местообитаний России и Монголии. Было выявлено два вероятных цитотипа для $S$. sanguinolenta, а также единичные образцы с кратными изменениями, и два цитотипа для S. borealis. Образцы с наименьшими цитотипами равны в среднем 0,32 и 0,38 пг для S. sanguinolenta и 0,36 пг для S. borealis. Исследованные образцы с крупными цитотипами распространены по большей части на территориях юго-западнее и южнее оз. Байкал и концентрируются по большей части на границах ареалов распространения S. sanguinolenta и S. borealis. Образцы с крупными цитотипами содержат ДНК в 1,5 раза больше (0,49 пг) и 2,2 раза больше (0,63 пг) для $S$. sanguinolenta и в 1,4 раза больше $(0,49$ пг) для S. borealis от наименьших цитотипов. Кроме того, в статье представлены результаты измерения содержания ДНК дополнительно для 7 видов группы sanguinolenta и 26 других видов рода Selaginella. Из исследованных таксонов данные для 27 видов приводятся впервые.

\section{Introduction}

Genus Selaginella P. Beauv. (Selaginellaceae) is one of the largest genera among vascular spore plants, numbering more than 700 species around the world. Representatives of the genus are distributed from alpine and arctic habitats to deserts and tropical forests. They are represented by terrestrial and epiphytic forms (Jermy, 1990; Zhang et al., 2013; Zhou et al., 2015; Zhou, Zhang, 2015; PPG I, 2016, Weststrand, Korall, 2016).

S. sanguinolenta s. 1. is a complex of morphologically related species distributed mainly in the central part of Asia from Afghanistan (in the west) to Okhotia (coast of the western part of the Sea of Okhotsk in the east) and from Yakutia (in the north) to the Himalayas and Yunnan province (in the south), with the exception of Central Asian deserts.

According to the system of Zhou and Zhang (2015), sanguinolenta-group is part of the subgenus Boreoselaginella Warb. with 3-5 species distributed in the Old World. The subgenus was described by O. Warburg in 1900 and included S. borealis (Kaulf.) Spring (incl. S. jacquemontii Spring), S. mongholica Rupr., S. yemensis (Sw.) Spring (incl. S. adunca R. Br.), S. rossii Warb. (S. mongholica Rupr. var. Rossi Bak.), S. arabica Bak. (Warburg, 1900). S. sanguinolenta (L.) Spring was placed by him in the subgenus Euselaginella. In the genus system proposed by Weststrand and Korall (2016), this sanguinolentagroup is assigned to the subgenus Stachygynandrum (P. Beauv. ex Mirb.) Baker. Based on morphological features, N. N. Tzvelev included this complex of species in the genus Lycopodioides Boehmer ex Ludwig section Stachygynandrum (P. Beauv. ex Mirb.) (Tzvelev, 2004).

Some authors consider this complex as one polymorphic species, and the others recognize some morphological forms as independent species (S. adunca, S. albocincta Ching, S. borealis, S. jacquemontii, S. aitchisonii Hieron, S. kansuensis Ching et Y. P. Hsu) (Tzvelev, 2004; Zhang et al., 2013; Fraser-Jenkins et al., 2015; Shalimov et al., 2019). This group is complex in structure and generally widespread, but some of its morphotypes are confined only to certain territories throughout the entire distribution area (S. adunca - Himalaya; S. aitchisonii - Himalaya, Hindu Kush, Tien Shan; S. albocincta - Тибет; S. jacquemontii - Himalaya, Hindu Kush; S. kansuensis - China (Gansu)). In addition to the complex $S$. sanguinolenta s. 1. we have analyzed species from the subgenus Boreoselaginella Warb., namely $S$. sajanensis Stepanov et Sonnikova (a species common in the Western Sayan Mountains), S. nummularifolia Ching (Tibet), $S$. rossii (Far East of Russia and Manchuria).

The morphology of the S. sanguinolenta-S. borealis complex is quite polymorphic in macrocharacters (leaves, sporophylls, shoots). Both clear morphological forms and numerous transitions between them are observed, which complicates the differentiation of these species and leads to their combination by some authors. In part, these can be explained by wide distribution area of the species and undoubted ancientry of the complex. S. sanguinolenta prefers drier and more open habitats, and $S$. borealis - 
shady and wetter regions (shady rocks of the forest belt or along river banks, and rocks of the northern exposure in open places). In some opinions, $S$. sanguinolenta can change the morphology under introduction, increased humidity and becomes more similar to $S$. borealis. "From the morphological point of view these plants cannot be considered separate species, but the question about the genetic differences between these species remains. From another point of view, knowledge of their polymorphism associated with environmental conditions allows us to consider them ecological races." (Ochirov, Namzalov, 2014: 33).

The different spore morphology of $S$. sanguinolenta and $S$. borealis indicates the independence these species (Vaganov et al., 2019).

In general, the problem of the complex is similar to the problems of the genus. Thus, evaluating the genus evolution, based on phylogenetic studies, many authors noticed parallelism of morphological characters and, based only on morphology, it is difficult to show the exact phylogeny of the family (Korall, Kenrick, 2002; Zhou et al., 2015; Weststrand, Korall, 2016). In addition, the sanguinolenta-group is difficult to correlate with other species of the genus, does not have a clear position on phylogenetic schemes and has recently been assigned closer to the stachygynandrum-clade (Weststrand, Korall, 2016; Zhang et al., 2019).

The difficulty in analyzing the ploidy of these species is in the small genome size of Selaginella. So, the average DNA content of one of the most studied species of the genus, diploid Selaginella moellendorffii, is $\approx 0.18 \mathrm{pg}$ (Wang et al., 2005) and the number of its chromosomes is 20. For example, the average size of one chromosome is more than 200 times smaller than the size of one chromosome of Allium robustum Kar. et Kir. (0.009 pg versus $1.925 \mathrm{pg}$ ) and 307 times less than in Eranthys sibirica DC. (Smirnov et al., 2017; Erst et al., 2020). In most cases, the availability of material suitable for chromosome analysis in the herbarium and living collections of the region is insufficient, as well as the analysis approaches, since the studied group, because of its meso- and xerophilicity, does not form rhizophores most often used to get squash preparations.

The aim of the study is to assess possible cytotypic variability and ploidy level in S. sanguinolenta and $S$. borealis. For this, we need to analyze the spreading of DNA content over the distribution area of the species and compare the obtained data with published data.

\section{Materials and methods}

We determined the DNA content $(2 \mathrm{C}, \mathrm{pg})$ using flow cytometry by staining of nuclei with propidium iodide. We used live and herbarium plant samples in the work. We crushed fresh leaves using a blade in $1 \mathrm{ml}$ of Tris- $\mathrm{MgCl}_{2}$ buffer containing propidium iodide $(50 \mu \mathrm{g} / \mathrm{ml})$, RNase $(10 \mu \mathrm{g} / \mathrm{ml})$ and 2-mercaptoethanol (0.2\%) (Pfosser et al., 1995). The dried herbarium material we crushed in $1 \mathrm{ml}$ of a buffer of the following composition: $50 \mathrm{mM}$ Hepes, $10 \mathrm{mM}$ sodium metabisulfite, $10 \mathrm{mM} \mathrm{MgCl}_{2}$, $0.5 \%$ polyvinylpyrrolidone, $0.2 \% \mathrm{BSA}, 0.3 \%$ Tween $20,0.2 \%$ Triton X-100, $50 \mu \mathrm{g} / \mathrm{ml}$ RNase, $1 \mu \mathrm{l} / \mathrm{ml} \beta$-mercaptoethanol, $50 \mu \mathrm{g} / \mathrm{ml}$ propidium iodide (Skaptsov et al., 2018). Samples were filtered through a $50 \mu \mathrm{m}$ nylon filter. The fluorescence data of isolated nuclei were detected using a Partec CyFlow PA flow cytometer (Partec, $\mathrm{GmbH}$ ) with a laser radiation source with a wavelength of $532 \mathrm{~nm}$. Cytometry data were processed using standard instrument software, Flowing Software 2.5.1 (Turku Center for Biotechnology) and XLSTAT software (AddinSoft). For the calculation, peaks with at least 5000 nuclei for living material and at least 1000 cores for herbarium samples were used. We used Selaginella kraussiana (Kunze) A. Braun as an external standard, $2 n=20 ; 2 \mathrm{C}=0.22 \mathrm{pg}$ (Little et al., 2007). We examined living material three times in three different days, dried material - three times using internal and external standardization. The ploidy level of $S$. kraussiana was confirmed by direct counting of the chromosomes, using the squash method of the root tips in 1\% acetoorceine (Tanaka, 1967).

\section{Results and discussion}

The studied species have rather small genome size and thereby the difficulty in studying the DNA content because of the technical problems of cytometry (for example, to avoid technical errors, it is recommended to use standard samples with a similar genome size with the studied ones (Obermayer et al., 2002)). Due to this and for comparing the results with previously published ones, we used $S$. kraussiana as a standard. This species is well defined morphologically, widespread and studied by many authors with flow cytometry (Little et al., 2007). However, the species has a polyploid row of $2 x, 3 x$ and $4 x$ with the number of chromosomes of 20, 30 and 40 (Obermayer et al., 2002; Marcon, 2003). We have counted the chromosomes and confirmed the ploidy of the used S. kraussiana 
sample - diploid with the number of chromosomes $2 n=20$.

Published data on the DNA content of diploid samples shows a wide range of the size, even within the one study, from 0.16 to $0.30 \mathrm{pg}$ (Little et al., 2007; Baniaga et al., 2016). In the work of Little et al. (2006), the number of chromosomes was dependent on the DNA content in the nucleus directly. In our study we analyzed the data on the number of chromosomes and the DNA content and compared the DNA content determined by us with the published data using the two-sided Fisher test. Our data confirmed the assumption of the dependence of the DNA content on the number of chromosomes at $p<0.0001(10,000$ Monte Carlo simulations, at $99 \%$ confidential interval). The Pearson correlation test showed a strong correlation between the DNA content and the number of chromosomes $(p<0.0008)$. In most cases, the differences between internal and external standardizations were not more than $0.01 \mathrm{pg}$, within the standard deviation.

\section{Cytotypic variability of $S$. sanguinolenta and $S$. borealis}

As a result of the work, we measured the DNA content of more than 50 samples of $S$. sanguinolenta and $S$. borealis. In the main, samples of the studied species were collected from the territories of Western and Eastern Siberia, the Far East of Russia, and Mongolia.

We identified two probable cytotypes for $S$. sanguinolenta, as well as single samples with multiple changes, and two cytotypes for $S$. borealis. $S$. sanguinolenta samples have the smallest cytotypes of 0.32 and $0.38 \mathrm{pg}$ on the average; S. borealis -0.36 and $0.52 \mathrm{pg}$. Samples with large cytotypes contain 1.5 times more DNA $(0.49 \mathrm{pg})$ and 2.2 times more $(0.63 \mathrm{pg})$ than the smallest cytotypes in S. sanguinolenta, and 1.4 times more $(0.49 \mathrm{pg})-$ in S. borealis (Table 1; Fig. 1a). The data on the number of chromosomes for $S$. sanguinolenta and $S$. borealis have not been presented, so it is not possible to determine the number of chromosomes by cytometry, because of large number of basic chromosome numbers known for the genus. In our case, triploid forms with differences in the main chromosome number are most likely presented, as well as single tetraploid and hexaploid for $S$. sanguinolenta and tetraploid for $S$. borealis. In addition, samples with the smallest cytotypes are characterized by a high standard deviation, which is apparently associated with hybridization processes between cytotypes in this territory.

Table 1

DNA content of the studied Selaginella species

\begin{tabular}{|c|c|c|c|c|c|}
\hline Species & $\begin{array}{c}\text { DNA } \\
\text { content } \\
(2 \mathrm{C} \pm \mathrm{SD}) \\
\mathrm{pg}\end{array}$ & Region & $\begin{array}{c}\text { Expected } \\
\text { ploidy } \\
\text { level* }\end{array}$ & $\begin{array}{l}\text { Published } \\
\text { DNA } \\
\text { content } \\
\text { (2C), pg }\end{array}$ & $\begin{array}{l}\text { Published } \\
\text { 2n/Ploidy }\end{array}$ \\
\hline S. sanguinolenta (L.) Spring & $\begin{array}{l}0.32 \pm 0.02 \\
0.38 \pm 0.04 \\
0.49 \pm 0.04 \\
0.63 \pm 0.05\end{array}$ & $\begin{array}{l}\text { East of Baikal, Russia } \\
\text { West of Baikal, Russia } \\
\text { West of Baikal, Russia } \\
\text { West of Baikal, Russia }\end{array}$ & $\begin{array}{l}3 \\
3 \\
4 \\
6\end{array}$ & & \\
\hline S. borealis (Kaulf.) Spring & $\begin{array}{l}0.36 \pm 0.01 \\
0.51 \pm 0.05\end{array}$ & $\begin{array}{l}\text { East of Baikal, Russia } \\
\text { West of Baikal, Russia }\end{array}$ & $\begin{array}{l}3 \\
4 \\
\end{array}$ & & \\
\hline S. adunca A. Braun & $0.20 \pm 0.01$ & Tibet, China & 2 & & \\
\hline S. aitchisonii Hieron. & $\begin{array}{l}0.25 \pm 0.01 \\
0.33 \pm 0.01\end{array}$ & Tibet, China & $\begin{array}{l}2 \\
3 \\
\end{array}$ & & \\
\hline S. jacquemontii Spring & $\begin{array}{l}0.21 \pm 0.02 \\
0.37 \pm 0.03\end{array}$ & $\begin{array}{l}\text { Tibet, China } \\
\text { Tibet, China }\end{array}$ & $\begin{array}{l}2 \\
4 \\
\end{array}$ & & \\
\hline S. kansuensis Ching et Y. P. Hsu & $0.25 \pm 0.01$ & Tibet, China & 2 & & \\
\hline S. nummularifolia Ching & $\begin{array}{l}0.30 \pm 0.03 \\
0.43 \pm 0.04\end{array}$ & Tibet, China & $\begin{array}{l}3 \\
4 \\
\end{array}$ & & \\
\hline S. rossii (Baker) Warb. & $\begin{array}{l}0.17 \pm 0.02 \\
0.29 \pm 0.04 \\
0.45 \pm 0.04\end{array}$ & Amur, Russia & $\begin{array}{l}2 \\
3 \\
4\end{array}$ & & $30 / 3^{(1)}$ \\
\hline $\begin{array}{l}\text { S. sajanensis Stepanov et } \\
\text { Sonnikova }\end{array}$ & $0.21 \pm 0.02$ & Amur, Russia & 2 & & \\
\hline S. albocincta Ching & $0.20 \pm 0.01$ & Sichuan, China & 2 & & \\
\hline
\end{tabular}


Table 1 (end)

\begin{tabular}{|c|c|c|c|c|c|}
\hline Species & $\begin{array}{c}\text { DNA } \\
\text { content } \\
(2 \mathrm{C} \pm \mathrm{SD}) \\
\mathrm{pg} \\
\end{array}$ & Region & $\begin{array}{l}\text { Expected } \\
\text { ploidy } \\
\text { level* }\end{array}$ & $\begin{array}{l}\text { Published } \\
\text { DNA } \\
\text { content } \\
(2 \mathrm{C}), \mathrm{pg} \\
\end{array}$ & $\begin{array}{l}\text { Published } \\
2 n / \text { Ploidy }\end{array}$ \\
\hline S. bellula W. Bull & $0.22 \pm 0.01$ & BGUO, 1996-0044-G & 2 & & \\
\hline $\begin{array}{l}\text { S. caulescens (Wall. ex Hook. et } \\
\text { Grev.) Spring }\end{array}$ & $0.18 \pm 0.01$ & BGUO, 1996-0048-G & 2 & $0.18^{(7)}$ & $20 / 2^{(2)}$ \\
\hline S. diffusa (C. Presl) Spring & $0.29 \pm 0.00$ & $\begin{array}{l}\text { BGUO, } \\
1998-0935-Z\end{array}$ & $3-4$ & & \\
\hline S. galcotti Spring & $0.17 \pm 0.01$ & BGUO, 1988-0751-G & 2 & & $20 / 2^{(2)}$ \\
\hline S. grandis Moore & $0.25 \pm 0.02$ & BGUO, 1986-0835-G & 2 & & $18 / 2^{(2)}$ \\
\hline S. helvetica (L.) Spring & $\begin{array}{l}0.22 \pm 0.01 \\
0.29 \pm 0.02\end{array}$ & $\begin{array}{l}\text { Tibet, China } \\
\text { Kurilskie island }\end{array}$ & $\begin{array}{l}2 \\
3\end{array}$ & $0.28^{(9)}$ & $18 / 2^{(1)}$ \\
\hline S. haematodes (Kunze) Spring & $0.19 \pm 0.01$ & BGUO, 1991-0728-W & 2 & & $20 / 2^{(2)}$ \\
\hline S. heterostachys Baker & $0.22 \pm 0.04$ & Tibet, China & 2 & & $\begin{array}{l}20 / 2^{(3)} \\
32 / 3^{(1)}\end{array}$ \\
\hline S. inaequalifolia Spring & $0.22 \pm 0.02$ & BGUO, 2010-0764-G & 2 & & \\
\hline S. leptophylla Baker & $0.20 \pm 0.01$ & Tibet & 2 & & $20^{(3)}$ \\
\hline S. martensii Spring & $0.45 \pm 0.02$ & BGUO, 1994-0130-G & $4-6$ & $0.20^{(8)}$ & $48-60^{(2)}$ \\
\hline S. moellendorfii Hieron. & $0.18 \pm 0.00$ & $\begin{array}{l}\text { Tibet, China } \\
\text { BGUO }\end{array}$ & 2 & $0.18^{(7)}$ & $20 / 2^{(1)}$ \\
\hline S. nipponica Franch. et Sav. & $0.22 \pm 0.02$ & Tibet, China & 2 & & $18 / 2^{(1,3)}$ \\
\hline S. palescens (Presl) Spring & $0.19 \pm 0.01$ & BGUO, 1985-1572-G & 2 & $0.22^{(7)}$ & $20 / 2^{(2)}$ \\
\hline $\begin{array}{l}\text { S. selaginoides (L.) P. Beauv. ex } \\
\text { Schrank et Mart. }\end{array}$ & $0.63 \pm 0.02$ & Irkutsk, Russia & $4-6$ & $0.16^{(8)}$ & $18 / 2^{(1,4)}$ \\
\hline S. serpens (Desv.) Spring & $0.17 \pm 0.02$ & BGUO, 1985-1302-G & 2 & & $20 / 2^{(2)}$ \\
\hline S. sibirica (Milde) Hieron. & $0.50 \pm 0.04$ & Irkutsk, Russia & $4-6$ & & $18 / 2^{(5)}$ \\
\hline S. sinensis (Desv.) Spring & $0.21 \pm 0.01$ & Beijing, China & 2 & & \\
\hline $\begin{array}{l}\text { S. tamariscina (P. Beauv.) } \\
\text { Spring }\end{array}$ & $\begin{array}{l}0.38 \pm 0.02 \\
0.50 \pm 0.02\end{array}$ & $\begin{array}{l}\text { Vietnam } \\
\text { Tibet, China }\end{array}$ & $4-6$ & & $\begin{array}{c}20- \\
22 / 2^{(1,3)}\end{array}$ \\
\hline S. tortipila A. Braun & $0.25 \pm 0.02$ & N. Carolina, USA & 2 & $0.24^{(8)}$ & \\
\hline S. umbrosa Lemaire ex Hieron & $0.20 \pm 0.02$ & BGUO, 1984-2303-G & 2 & & $20 / 2^{(2)}$ \\
\hline S. uncinata (Desv.) Spring & $0.42 \pm 0.01$ & BGUO, 1988-0750-G & 4 & $0.18^{(7)}$ & $18 / 2^{(1,6)}$ \\
\hline S. vaginata Spring & $0.32 \pm 0.01$ & Tibet, China & 3 & & \\
\hline S. viticulosa Klotzsch & $0.17 \pm 0.01$ & BGUO, 1998-0938-Z & 2 & & $20 / 2^{(2)}$ \\
\hline S. vogeli Spring & $0.34 \pm 0.02$ & BGUO, 1984-1690-G & 3 & & $27 / 3^{(2)}$ \\
\hline \multicolumn{6}{|c|}{$\begin{array}{l}\text { *Expected ploidy level according to DNA content - based on the literature data (chromosome counts and } \\
\text { distribution of DNA content for diploid) and our measurements (cytometry data). } \\
\text { East of Baikal - Eastern Siberia (Irkutsk Region, Trans-Baikal Territory), the Far East of Russia, and Mongolia. } \\
\text { West of Baikal - Republic of Tuva, Krasnoyarsk Territory. } \\
\text { BGUO - The Botanical Garden of the University of Osnabrück, Germany, Live collection. } \\
\text { 'Takamiya, } 1993 ;{ }^{2} \text { Jermy et al., } 1967 ;{ }^{3} \text { Tsai, Shieh, } 1988 ;{ }^{4} \text { Love, Love, } 1976 ;{ }^{5} \text { Zhukova, Petrovsky, } 1975 ;{ }^{6} \text { Weng, } \\
\text { Qiu, 1988; }{ }^{7} \text { Little et al., 2007; }{ }^{8} \text { Baniaga et al., 2016; }{ }^{9} \text { Siljak-Yakovlev, } 2010 .\end{array}$} \\
\hline
\end{tabular}

The studied samples with large cytotypes are distributed mainly in the territories southwest and south of the Baikal Lake. The Mann-Whitney U-test showed significant differences between the DNA content values in the regions west and southwest of Baikal Lake (Tuva, Krasnoyarsk Territory), more than the east of Baikal Lake (Buryatia, Irkutsk Region, Trans-Baikal Territory) $(\mathrm{p}<0.0001)$.

The diversity of $S$. sanguinolenta and $S$. borealis cytotypes observed by us and their concentration in these regions are evidently associated with large geographical barriers, such as the Katun, Yenisei and Selenga Rivers. There is no information in the literatureaboutfurtherdistribution of S. sanguinolenta and $S$. borealis to the west. Apparently, there is a concentration of different forms of $S$. sanguinolenta and $S$. borealis variable both cytotypically and morphologically in these regions. A similar picture is not unique to the plant world and has previously been described in literary sources for species at the 
borders of the area. Plants growing at the borders of the area often have chromosomal abnormalities, mixoploidy, and especially the high-ploid cytotypes (Sokolovskaya, 1982; Muratova, 1995; Probatova, 2007; Khrolenko, Muratova, 2016). Undoubtedly, this fact has a certain meaning in the evolution, since polyploids have a great variability and adaptability to new ecological niches (Grant, 1981; Van de Peer et al., 2017).

\section{About the genome size of some species of the genus Selaginella}

In addition to the $S$. sanguinolenta-S. borealis complex, we have analyzed other species of the subgenus Boreoselaginella: $S$. adunca, S. jacquemontii, S. rossii, S. aitchisonii, S. kansuensis, S. sajanensis, S. nummularifolia (herbarium material), as well as some species from other groups of the genus Selaginella, cultivated in greenhouse conditions in the South Siberian Botanical Garden and kindly transferred to us from the living collection of the Botanical Garden in Osnabruck, Germany (Table 1; Fig. 1).

There were no problems with living material, including the number of isolated nuclei for analysis, as well as the quality of the histograms. Herbarium samples were also preserved good. The data on samples of 10-20 years old (Fig. 1j, i) did not differ from fresh and even living samples practically. But for older material, an increase of peak of coefficient of variation $(\mathrm{CV})$ on histograms, decrease of the number of positive events (nuclei), or the appearance of too much debris from destroyed nuclei with a reduced content of DNA ("noise") were often characteristic. This phenomenon often depends on the quality of herbarization and storage of the material (color change to straw yellow or

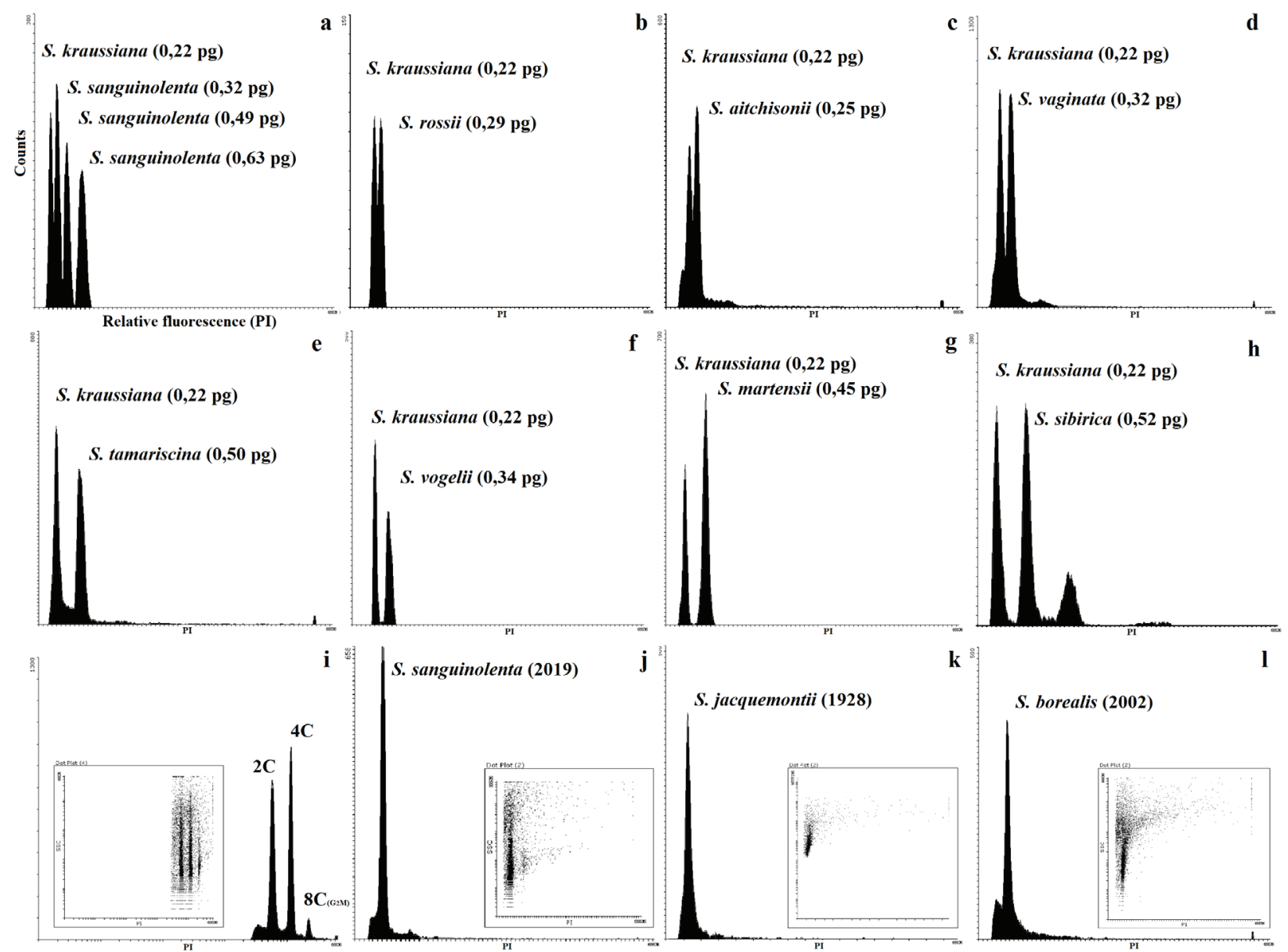

Fig. 1. Histograms of some studied Selaginella species: a) S. sanguinolenta cytotype series; b) S. rossii cytotype, possibly according to Takamiya, 1993 triploid specimen $(2 n=30)$; c) S. aitchisonii; d) S. vaginata; e) S. tamariscina; f) S. vogelii; g) S. martensii; h) S. sibirica; i) S. sibirica, endopolyploidy demonstration (log scale); j) S. sanguinolenta (2019 year of herbarization); k) S. jacquemontii (1928 year of herbarization); 1) S. borealis (2002 year of herbarization). 
pale green, fragility) directly. It was also noted in the work of Little et al. (2007), which provides data for samples with a maximum of 14 years old. Herbarium material should be naturally green color, with no signs of disease or damage. In our work, S. jacquemontii collected in 1928 (Fig. 1k), was one of the oldest studied samples with a fairly low "noise" level and a "shaped" peak, but in most cases, samples older than the 1950-1960 years, are not suitable for the study of ploidy and especially the DNA content.

For most Selaginella species studied, diploids with the number of chromosomes $2 n=18$ and 20, the main chromosome numbers $x=9$ and $x=10$ are known. Less commonly, $2 n=16,22,24$ (Loyal, Kumar, 1984; Wang, Xia, 1984; Tindale, 2002). In general, the number of chromosomes varies in the range from $2 n=14$ to $2 n=60$; different authors reported different main numbers of chromosomes: $x=7,8,9,10,11$, and 12 (Kuriachan, 1963; Jermy et al., 1967; Takamiya, 1993; Marcon et al., 2005).

There are few data on polyploid samples. The most famous polyploid series is $S$. kraussiana $2 n=$ 20, 30, $40(x=10)$, hexaploids $S$. martensii Spring $2 n=48$ to $60(x=$ ?), and $S$. martensii var. divaricata A. Br. $2 n=60(x=10)$, triploids $S$. vogelii Spring, S. biformis A. Braun ex Kuhn, S. bluuensis Alderw. $2 n=27(x=9)$, tetraploids $S$. longiciliata Hieron. and $S$. radicata Hort. ex Alston $2 n=36(x=9)$, S. platybasis Baker and $S$. porelloides (Lam.) Spring $2 n=36-40$, S. stenophylla A. Braun $2 n=50-60(x=$ ?) (Heitz, 1926; Jermy et al., 1967; Vasadueva, Bir, 1983; Takamiya, 1993).

Often when examining plants with flow cytometry, researchers detected an endopoliploidy. The endopolyploidy is common in flowering plants. Among spore plants it is ubiquitous in mosses, but practically absent in ferns (Bainard, Newmaster, 2010; Skaptsov et al., 2017). The endopoliploidy is often associated with heterosporia (for example, in mosses), which is also common in Selaginella. However, there was no endopoliploidy in the studied species, except S. sibirica (Milde) Hieron. (Fig. 1i).

Overall, our data are consistent with published data, both on the species already studied by cytometry: S. moellendorfii Hieron, S. caulescens (Wall. ex Hook. et Grev.) Spring, S. palescens (Presl) Spring, S. tortipila A. Braun, and indirectly, based on published chromosome numbers. For example, $S$. nipponica Franch. et Sav. $(0.22 \mathrm{pg} / 2 n=18)$, $S$. serpens (Desv.) Spring $(0.17 \mathrm{pg} / 2 n=20)$,
S. vogelli $(0.34 \mathrm{pg} / 2 n=27)$ and others showed DNA content close to the number of chromosomes according to published data as we expected (table. 1). In addition, two cytotypes were identified for S. helvetica (L.) Spring -0.22 and $0.29 \mathrm{pg}$.

For species with no data on the number of chromosomes ( $S$. albocincta, S. sinensis (Desv.) Spring, S. vaginata Spring, S. diffusa (C. Presl) Spring, etc.), it was not possible to determine the number of chromosomes without direct counting because of the large number of variants of the main chromosome numbers.

For widely distributed circumpolar S. sibirica, S. selaginoides (L.) P. Beauv. ex Schrank et Mart. and tropical $S$. uncinate (Desv.) Spring, S. tamariscina (P. Beauv.) Spring, genome sizes or the number of chromosomes is known as for diploids. But we showed a significantly higher ploidy, for example, S. uncinata (Desv.) Spring in our study has DNA content $(0.48 \mathrm{pg})$ in 2.66 times more than diploid samples from the literature data $(0.18 \mathrm{pg})$, and $S$. selaginoides has DNA content $(0.63 \mathrm{pg})$ in 3.9 times more $(0.16 \mathrm{pg})$ than diploid samples from the literature (Little et al., 2007; Baniaga et al., 2016).

The study of the DNA content of other representatives of the sanguinolenta-group showed similar results with other representatives of the genus: from $0.17 \mathrm{pg}$ for $S$. rossii to $0.25 \mathrm{pg}$ for $S$. aitchisonii and S. kansuensis. Larger cytotypes suggesting greater ploidy were identified analogically. So, three cytotypes were revealed for $S$. rossii (one of them, apparently, is consistent with the triploid sample studied by Takamiya, 1993), and two cytotypes for S. jacquemontii, S. nummularifolia and S. aitchisonii each. This consistency proves similar microevolutionary processes such as polyploidy, which are characteristic of the sanguinolenta-group.

Based on the studied cytotypes of $S$. borealis$S$. sanguinolenta, we can assume that a similar evolutionary model associated with cytotypic variation across the distribution area is possible in other groups of the genus. We partially showed this on other species of the subgenus Boreoselaginella (S. rossii, S. jacquemontii, $S$. nummularifolia, $S$. aitchisonii), but, due to the single representation of these species in herbarium collections or the large age of the collected material, which is difficult to study by flow cytometry and impossible karyotyping, it is difficult to evaluate the complete scheme of microevolutionary processes, like the S. borealis-S. sanguinolenta complex. Nevertheless, 
these problems could be resolved by large-scale phylogeographic studies for each group of the genus individually, using methods of cytogenetics and molecular genetics - classical genosystematics or haplotyping on modern NGS platforms.

\section{Acknowledgements}

We are grateful to the curators of Herbaria of the CSBG SB RAS (NS, NSK), the ISU (Smirnov
Herbarium, IRKU), Komarov BIN RAS (LE), Lomonosov MSU (Syreyshchikov Herbarium, MW), SIPPB SB RAS (IRK), Institute of Biology NAS, Kyrgyz Republic (FRU) and D. N. Shaulo, S. G. Kasanovsky, V. V. Chepinoga and G. A. Lazkov for the opportunity to work with collections.

This work was supported by the Russian Foundation for Basic Research (Project No. 18-54-53026 GFEN_a).

\section{References}

Bainard J. D., Newmaster S. G. 2010. Endopolyploidy in Bryophytes: Widespread in Mosses and absent in Liverworts. Journal of Botany 2010(316356): 1-7. DOI:10.1155/2010/316356

Baniaga A. E, Arrigo N., Barker M. S. 2016. The small nuclear genomes of Selaginella are associated with a low rate of genome size evolution. Genome Biology and Evolution 8: 1516-1525.

Dmitrieva S. A., Parfenov V. I. 1991. Kariologiya flory kak osnova tsitogeneticheskogo monitoringa: (na primere Berezinskogo biosfernogo zapovednika) [Karyology of flora as the basis of cytogenetic monitoring (on the example of the Berezinsky Biosphere Reserve)]. Minsk: Science and Technology. 230 pp. [In Russian] (Дмитриева С. А., Парфенов В. И. Кариология флоры как основа цитогенетического мониторинга (на примере Березинского биосферного заповедника). Минск: Наука и техника, 1991. 230 с.).

Erst A. S., Sukhorukov A. P., Mitrenina E. Y., Skaptsov M. V., Kostikova V. A., Chernisheva O. A., Troshkina V., Kushunina M., Krivenko D. A., Ikeda H., Xiang K., Wang W. 2020. An integrative taxonomic approach reveals a new species of Eranthis (Ranunculaceae) in North Asia. PhytoKeys 140: 75-100. DOI: 10.3897/phytokeys.140.49048

Fraser-Jenkins $\boldsymbol{C}$. R., Kandel D. R., Pariyar S. 2015. Ferns and fern-allies of Nepal. Vol. 1. National Herbarium and Plant Laboratories, Department of Plant Resources, Ministry of Forests and Soil Conservation, Kathmandu, 508 pp.

Grant V. 1981. Plant Speciation. New York. 346 pp.

Heitz E. 1926. Der Nachweis der Chromosomen. Zeitschrift für Botanik 18: 625-681.

Jermy A. C. 1990. Selaginellaceae. In: The families and genera of vascular plants. Pteridophytes and gymnosperms. Eds. K. U. Kramer, P. S. Green. Vol. 1. Berlin, Heidelberg et New York. Pp. 39-45. DOI: 10.1007/978-3-66202604-5

Jermy A. C., Jones K., Colden C. 1967. Cytomorphological variation in Selaginella. Botanical Journal of the Linnean Society 60: 147-158. DOI: 10.1111/j.1095-8339.1967.tb00083.x

Khrolenko Yu. A., Muratova E. N. 2016. Karyology of Senecio cannabifolius (Asteraceae) from Kamchatka peninsula. Bot. Zhurn. (Moscow \& St. Petersburg) 101(4): 416-427. [In Russian] (Хроленко Ю. А., Муратова E. Н. Кариология Senecio cannabifolius (Asteraceae) с полуострова Камчатка // Бот. журн., 2016. Т. 101, № 4. С. 416-427).

Korall P., Kenrick P. 2004. The phylogenetic history of Selaginellaceae based on DNA sequences from the plastid and nucleus: Extreme substitution rates and rate heterogeneity. Molecular Phylogenetics and Evolution 31: 852-864. DOI: 10.1016/j.ympev.2003.10.014

Kuriachan P. I. 1963. Cytology of the genus Selaginella. Cytologia 28: 376-380. DOI: 10.1508/cytologia.28.376

Little D., Moran R., Brenner E., Stevenson D. 2007. Nuclear genome size in Selaginella. Genome 50: 351-356. DOI: $10.1139 / \mathrm{G} 06-138$

Love A., Love D. 1976. In IOPB chromosome number reports LIII. Taxon 25: 483-500.

Loyal D. S., Kumar V. 1984. Cytotaxonomic observations on three Selaginella species from North-Western Himalayas. Indian Fern Journal 1: 59-62.

Marcon A. B. 2003. Karyology of some Pteridophytes species occurring in the north-east of Brazil. Acta Botanica Brasilica 17(1): 19-26. DOI: 10.1590/S0102-33062003000100002

Marcon A. B., Barros I. C., Guerra M. 2005. Variation in chromosome numbers, CMA bands and 45S rDNA sites in species of Selaginella (Pteridophyta). Annals of botany 95(2): 271-276. DOI: 10.1093/aob/mci022

Muratova E. N. 1995. Kariosistematika semeystva Pinaceae Lindl. Sibiri i Dalnego Vostoka [Karyosystematics of family Pinaceae Lindl. Siberia and the Far East: Abstr. Doct. Diss.]. Novosibirsk. 32 pp. [In Russian] (Mypamoвa $\boldsymbol{E}$. H. Кариосистематика семейства Pinaceae Lindl. Сибири и Дальнего Востока: Автореф. дис. ... докт. биол. наук. Новосибирск, 1995. 32 с.).

Obermayer R., Leitch I. J., Hanson L., Bennett M. D. 2002. Nuclear DNA C-values in 30 species double the familial representation in pteridophytes. Annals of Botany 90: 209-217. DOI: 10.1093/aob/mcf167 
Ochirov Ch. S., Namzalov B. B. 2014. On the issue of the history of the genus Selaginella (L.) Beauv., of the area and ecological features of $S$. sanguinolenta (L.) Spring in Central Asia. Vestnik Buryatskogo gosudarstvennogo universiteta. Biologiya, geografiya [The Buryat State University Bulletin. Biology, Geography] 4(2): 30-33. [In Russian] (Очиров Ч. С., Намзалов Б. Б. К вопросу об истории рода Selaginella (L.) Beauv, apeале и экологических особенностях S. sanguinolenta (L.) Spring в Центральной Азии // Вестник Бурятского государственного университета. Биология, география, 2014. № 4(2). С. 30-33).

Pfosser M., Heberle-Bors E., Amon A., Lelley T. 1995. Evaluation of sensitivity of flow-cytometry in detecting aneuploidy in wheat using disomic and ditelosomic wheat-rye addition lines. Cytometry 21: 387-393. DOI: 10.1002/ cyto.990210412

PPG I. 2016. A community derived classification for extant lycophytes and ferns. Journal of Systematics and Evolution 54(6): 563-603. DOI: 10.1111/jse.12229

Probatova N. S. 2007. Chromosome numbers in Poaceae family and their significance for taxonomy, phylogeny and phytogeography (using the example of the cereals of the Russian Far East). Komarovskiye chteniya [V. L. Komarov Memorial Lectures] 55: 9-103. [In Russian] (Пробатова Н. С. Хромосомные числа в семействе Роасеае и их значение для систематики, филогении и фитогеографии (на примере злаков Дальнего Востока России) // Комаровские чтения, 2007. Вып. 55. С. 9-103).

Shalimov A. P., Wu Y.-D., Zhang X.-C. 2019. A taxonomic revision of the genus Selaginella (Selaginellaceae) from Nepal. PhytoKeys 133: 1-76. DOI: 10.3897/phytokeys.133.37773

Siljak-Yakovlev S., Pustahija F., Šolic E. M., Bogunic F., Muratovic E., Bašic N., Catrice O., Brown S.C. 2010. Towards a genome size and chromosome number database of Balkan flora: C-values in 343 taxa with novel values for 242. Advanced Science Letters 3: 190-213. DOI: 10.1166/asl.2010.1115

Skaptsov M. V., Lomonosova M. N., Kutsev M. G., Smirnov S. V., Shmakov A. I. 2017. The phenomenon of endopolyploidy in some species of the Chenopodioideae (Amaranthaceae). Botany Letters 164(1): 47-53. DOI: 10.1080/23818107.2016.1276475

Skaptsov M. V., Smirnov S. V., Kechaykin A. A., Kutsev M. G., Vaganov A. V., Zhang X.-C., Shmakov A. I. 2018. Polymorphism of the relative DNA content of the species Selaginella borealis and Selaginella sanguinolenta. Acta Biologica Sibirica 4, 4: 116-118. DOI: 10.14258/abs.v4.i4.4903

Smirnov S., Skaptsov M., Shmakov A., Fritsch R., Friesen N. 2017. Spontaneous hybridization among Allium tulipifolium and A. robustum (Allium subg. Melanocrommyum, Amaryllidaceae) under cultivation. Phytotaxa 303(2): 155-164. DOI: 11646/phytotaxa.303.2.5

Sokolovskaya A. P. 1982. Polyploidy among flowering plants of different landscapes of the USSR. Trudy Leningradsk. Obshch. Estestvoisp. Otdeleniye botaniki [Proceedings of the Leningrad Society of Naturalists] 75(3): 1-128. [In Russian] (Соколовская А. П. Труды Ленинградского общества естествоиспытателей. Отделение ботаники, 1982. T. 75, № 3. C. 1-128).

Takamiya M. 1993. Comparative karyomorphology and interrelationships of Selaginella in Japan. Journal of Plant Research 106: 149-166. DOI: 10.1007/BF02344419

Tanaka $\boldsymbol{R}$. 1967. A comparative karyotype analysis in Haplopappus gracilis $(2 n=4)$ and Haplopappus ravenii $(2 n$ =8). Cytologia 32: 542-554. DOI: 10.1508/cytologia.32.542

Tindale M. D., Roy S. K., 2002. A cytotaxonomic survey of the Pteridophyta of Australia. Australian Systematic Botany 15: 839-937. DOI: 10.1071/SB00034

Tsai J. L., Shieh W. C. 1988. Cytotaxonomic studies on the Selaginellaceae in Taiwan. Journal of Science and Engineering 25: 83-92.

Tzvelev N. N. 2004. De genere Selaginella P. Beauv. (Selaginellaceae) in Rossia. Novosti sistematiki vysshikh rasteniy [Novit. Syst. Pl. Vasc.] 36: 22-27. [In Russian] (Цвелев Н. Н. О роде Selaginella P. Beauv. s. 1. (Selaginellaceae) в России // Новости сист. высш. раст., 2004. Т. 36. С. 22-27).

Vaganov A. V., Shalimov A. P., Kechaykin A. A., Skaptsov M. V., Smirnov S. V., Sinitsyna T. A., Kutsev M. G., Zhang X.-C., Shmakov A. I. 2019. Spore morphology of Selaginella borealis, S. sanguinolenta and S. helvetica (Selaginellaceae, Lycopodiophyta). Turczaninowia 22, 2: 142-150. DOI: 10.14258/turczaninowia.22.2.10

Van de Peer Y., Mizrachi E., Marchal K. 2017. The evolutionary significance of polyploidy. Nature Reviews Genetics 18: 411-424. DOI: 10.1038/nrg.2017.26

Vasudeva S. M., Bir S. S. 1983. Chromosome numbers and evolutionary status of ferns and fern allies of Pachmarhi Hills (Central India). Aspects of Plant Science 6: 119-181.

Wang W., Tanurdzic M., Luo M., Sisneros N., Kim H. R., Weng J. K., Kudrna D., Mueller C., Arumuganathan K., Carlson J., Chapple C., de Pamphilis C., Mandoli D., Tomkins J., Wing R. A., Banks J. A. 2005. Construction of a bacterial artificial chromosome library from the spikemoss Selaginella moellendorffii: a new resource for plant comparative genomics. BMC plant biology 5: 10. DOI: 10.1186/1471-2229-5-10

Wang Z., Xia Q. 1984. Cytological observations on some species of Dryopteris and Polystichum from China. Acta Botanica Sinica 26: 1-10.

Warburg O. 1900. Selaginellaceae. Monsunia 1: 100-136. 
Weng R. F., Qiu S. P. 1988. Chromosome counts of some ferns from Zhejiang. Invest. Stud. Nat. 8: 43-52.

Weststrand S., Korall P. 2016. Phylogeny of Selaginellaceae: There is value in morphology after all! American Journal of Botany 103: 2136-2159. DOI:10.3732/ajb.1600156

Zhang H.-R., Xiang Q.-P., Zhang X.-C. 2019. The unique evolutionary trajectory and dynamic conformations of DR and IR/DR-Coexisting plastomes of the early vascular plant Selaginellaceae (Lycophyte). Genome Biology and Evolution 11(4): 1258-1274. DOI: 10.1093/gbe/evz073

Zhang X.-C., Kato M., Nooteboom H. P. 2013. Selaginellaceae. In: Flora of China. Eds. Z. Y. Wu, P. H. Raven, D. Y. Hong. Vol. 2-3. Beijing, St. Louis. Pp. 37-66.

Zhou X.-M., Rothfels C. J., Zhang L., He Z.-R., Le Péchon T., He H., Lu N. T., Knapp R., Lorence D., He X.-J., Gao X.-F., Zhang L.-B. 2015.A large-scale phylogeny of the lycophyte genus Selaginella (Selaginellaceae: Lycopodiopsida) based on plastid and nuclear loci. Cladistics 32: 360-389. DOI: 10.1111/cla.12136

Zhou X.-M., Zhang L.-B. 2015. A classification of Selaginella (Selaginellaceae) based on molecular (chloroplast and nuclear), macromorphological, and spore features. Taxon 64: 1117-1140. DOI: 10.12705/646.2

Zhukova P. G., Petrovskiy V. V. 1976. Chromosome numbers of some western Chukotka plant species, II. Bot. Zhurn. (Moscow \& Leningrad) 61(7): 963-969. [In Russian] (Жукова П. Г., Петровский В. В. Хромосомные числа некоторых видов растений Западной Чукотки. II // Бот. журн., 1976. Т. 61, № 7. С. 963-969). 